\title{
Concurrent acute kidney injury and acute hepatitis resulting from raw fish gallbladder ingestion: a preventable cause of community acquired organ damage
}

\author{
Haque MR ${ }^{a}$, Ahmed SM ${ }^{b}$, Chowdhury TA ${ }^{c}$, Rahim MAd, Ananna MA', Iqbal $S^{e}$
}

\begin{abstract}
ABS TRACT
In south-east Asia, there has been a common belief, mainly in rural areas, that ingesting raw fish gall bladder can help cure certain health problems. Unfortunately, raw fish bile has both nephrotoxic and hepatotoxic effects. In this report, we present a case of 42-year-old man, who presented with acute kidney injury and jaundice. Meticulous history revealed that his ailment resulted from raw Rohu fish gallbladder ingestion.
\end{abstract}

Key words: acute kidney injury, fish gall bladder, hemodialysis, jaundice, Rohu fish.

(BIRDEM Med J 2021; 11(1): 70-71)

\section{INTRODUCTION}

Due to frequent consumption of fish gall bladder for the purpose of curing rheumatism, asthma and improving vision, fish bile poisoning cases are commonly reported in China, India, Japan and other Asian countries. ${ }^{1}$ Fish bile poisoning have significant morbidity and mortality. ${ }^{2}$ Recently, studies have shown that fish gallbladder can damage to the heart, liver and gastrointestinal tract and lead to multiple organ dysfunction syndrome (MODS). ${ }^{3}$ Most patients present

\section{Author information}

a. Md. Rezwanul Haque, Assistant Registrar, Department of Neurology, BIRDEM General Hospital, Dhaka, Bangladesh.

b. Syed Mohaimeen Ahmed, Resident Medical Officer, Department of Neurology, BIRDEM General Hospital, Dhaka, Bangladesh.

c. Tufayel Ahmed Chowdhury, Registrar, Department of Nephrology, BIRDEM General Hospital, Dhaka, Bangladesh.

d. Muhammad Abdur Rahim, Mehbuba Alam Ananna, Associate Professor, Department of Nephrology, BIRDEM General Hospital, Dhaka, Bangladesh.

e. Sarwar Iqbal, Professor, Department of Nephrology, BIRDEM General Hospital, Dhaka, Bangladesh.

Address of correspondence: Md. Rezwanul Haque, Assistant Registrar, Department of Neurology, Room-1417, BIRDEM General Hospital, Shahbag, Dhaka-1000, Bangladesh. Email: rezwan0103@gmail.com

Received: September 9, 2020

Revision received: September 20, 2020

Accepted: October 31, 2020 with nausea, vomiting, abdominal pain, watery diarrhea from a few minutes to several hours after eating, followed by manifestation of the central nervous system (CNS), oliguria due to acute kidney injury (AKI) and toxic hepatitis. ${ }^{4}$ As this is an overlooked cause of simultaneous AKI and hepatitis, we here in present a case of fish gallbladder poisoning, to create awareness among physicians in recognizing and managing such cases.

\section{CASE REPORT}

A 42-year-old man, known case of ischaemic heart disease and hypertension, presented with 3-day history of vomiting, watery stool and diffuse abdominal pain. Two days later, he developed reduced urine output and yellowish discoloration of skin and sclera. Patient did not take non-steroidal anti-inflammatory drugs (NSAIDs) or other nephrotoxic and hepatotoxic drugs. No history of exposure to chemicals or toxins was found. No other family members were affected. Patient was initially treated in a local hospital, where his serum creatinine $(6.8 \mathrm{mg} / \mathrm{dl})$ and serum alaline aminotranferase (ALT) $(2408 \mathrm{U} / \mathrm{L})$ levels were found elevated. Meticulous history was taken for searching possible cause of concurrent renal and hepatic impairment and patient admitted taking raw Rohu fish (a member of carp family) gallbladder to cure peptic ulcer disease (PUD) 1 day before symptom onset. 
At our center, clinical evaluation revealed tachycardia (heart rate 108 beats/min), icterus and dehydration. Abdominal examination revealed diffuse tenderness without any organomegaly. Bed side urine examination showed trace of protein. Other systemic examination findings were normal.

Patient had leukocytosis and raised erythrocyte sedimentation rate (ESR) (30 mm in 1st hour). Serum creatinine and serum urea levels were $7.6 \mathrm{mg} / \mathrm{dl}$ and 126 $\mathrm{mg} / \mathrm{dl}$ respectively. His serum electrolytes revealed hyponatremia (serum $\mathrm{Na} 127 \mathrm{mmol} / \mathrm{L}$ ), hyperkalemia (serum K $6.8 \mathrm{mmol} / \mathrm{l}$ ) with metabolic acidosis (serum $\mathrm{HCO}_{3} 19 \mathrm{mmol} / \mathrm{L}$ ). His serum ALT and aspartate aminotransferase (AST) level were $373 \mathrm{U} / \mathrm{L}$ and $943 \mathrm{U} / \mathrm{L}$ respectively. Serum bilirubin level was $4.1 \mathrm{mg} / \mathrm{dl}$ and serum alkaline phosphatase level was $70 \mathrm{U} / \mathrm{L}$. Urine routine examination showed presence of red blood corpuscles (RBC) (20-30/high power field) with trace protein.

As patient's urine output was still low and features of uremia developed despite proper conservative management, hemodialysis was started. After 6 sessions of hemodialysis, patient's urine output started increasing and other biochemical parameters also gradually came back to normal level. Patient was discharged with the advice of follow-up after 1 month. On follow-up visit, patient had normal clinical and biochemical parameters.

\section{DISCUSSION}

Most of fish poison contains ciguatoxin ${ }^{5}$ and mackerel poison mainly found in marine coral fish. Although carp fish is non-poisonous, its bile contains highly virulent bile toxins like water soluble sodium cyprinol sulphate which can lead to MODS. ${ }^{6}$ Toxicity is directly proportional to the size and quality of the gallbladder and bile content. ${ }^{7}$ Renal failure is the most commonly reported effect of fish bile poisoning. ${ }^{8}$ Cyprinol and related compounds in fish gall bladder are thought to be the cause of acute tubular necrosis in such cases. ${ }^{9}$ Furthermore, frequent vomiting, diarrhea and insufficient fluid intake can worsen renal failure due to significantly decreased intravascular fluid volume. ${ }^{2}$

AKI after fish gall bladder ingestion has a variable prognosis. However, death may result from fulminant hepatic failure. ${ }^{7}$ Treatment comprises of hemodialysis and supportive management ${ }^{9}$ and most of the reported cases till date have undergone hemodialysis in view of renal failure. The patient in the reported case also responded to the same line of management.

Simultaneous renal and liver injury may result from exposure to a variety of toxins, infections including malaria and leptospirosis but in absence of any history suggesting toxin exposure or fever, the possibility of ingestion of raw fish gallbladder and bile should be considered. As proper management can save lives in such cases, high degree of suspicion and proper clinical history should be elicited in order to ensure early detection of cases and timely management.

Authors' contribution: MRH managed the case, did literature search and drafted the manuscript. SMA did literature search and helped in drafting the manuscript. TAC supervised managing the case. MAR supervised managing the case, revised and edited the manuscript. MAA diagnosed the case and supervised managing the case. SI was the overall supervisor. All authors read and approved the final manuscript.

Conflict of interest: Nothing to declare.

Consent: Written informed consent was obtained from the patient for publication of this case report and any accompanying images.

\section{REFERENCES}

1. Chan DW, Yeung CK, Chan MK. Acute renal failure after eating raw fish gall bladder. Br Med J 1985 Mar; 290:897.

2. Pandey NR, Yoo BY, Khakurel S. Acute renal failure after consumption of fish Gall Bladder. Hindawi 2014; Article ID194129 .

3. Cheng XL, Wang ZI, Reng LM. Fish gall bladder poisoning damage liver, renal and heart. Chin J Integr Med 1991; 3:2389 .

4. Chen WT, Yen TS, Chen JT, Hsieh BS, Hsu HC. Acute renal failure due to ingestion of raw bile grass carp (Ctenopharyn godenidellus). J Formosan Med Assoc 1976; 75:149-57.

5. Perez CM, Vasquez PA, Perret CF. Treatment of ciguatera poisoning with gabapentin. N Engl J Med 2001;344(9):6923.

6. Singh NS, Singh LKS, Khaidem I, Singh G, Reddy VRS, Bawi NS, et al. Acute renal failure following consumption of raw fish gall bladder from Manipur. J Assoc Physicians India 2004; 52:743-5.

7. Xuan BH, Thi TX, Nguga ST, Goldfarb DS, Stokes MB, Raberow RA. Ichthyotoxic ARF after fish gall bladder ingestion: A large case series from Vietnam. Am J Kidney Dis 2003 Jan; 41(1): 220-4.

8. Goldstein SJ, Raja RM, Kramex M, Hirsch W, Mey FB. Acute hepatitis and renal failure following ingestion of raw carp gall bladder- Maryland and Pennsylvania, 1991 and 1994. J Am Med Assoc August 4, 1995; 44(30); 565-6.

9. Samad T, Haque WMM, Rahim MA, Iqbal S, Mitra P. Community Acquired Acute Kidney Injury from Edible agents: Report from a Developing Country, Bangladesh. Open Urol Nephrol J 2017; 10:20-8. 